\title{
Simulation of Flow-mode Performance due to Harmonic and Abrupt Excitation
}

\author{
Reiza Zakia Mukhlis, Nik Adbullah Nik Mohamed and Mohd Jailani Mohd Nor
}

\author{
MEMS-Automotive Research Group \\ Department of Mechanical and Materials Engineering \\ Universiti Kebangsaan Malaysia \\ 43600 Bangi, Selangor, \\ Malaysia
}

Received Date: $29^{\text {th }}$ August 2006 Accepted Date: 14 $4^{\text {th }}$ February 2007

\begin{abstract}
This paper discusses the performance of the suspension system that implements the flow-mode electrorheological damper in controlling the unwanted vibration caused by road surface irregularities. First, a mathematical model to determine damping coefficient of the damper was developed based on the fluid flow behavior in the gap between two electrodes. To evaluate the performance, the system is then simulated in two kind of road excitation; abrupt excitation and harmonic excitation. The performance is characterised by the level of ride comfort and road handling. The passenger ride comfort was evaluated by the force transmitted from the road to the passenger and by the vertical acceleration of the sprung mass, while the vehicle road handling was evaluated by the wheel hop and the amplification ratio. The result showed that the system can obtain the best compromise between road handling and ride comfort by adjusting the electric field strength that is applied to the damper.
\end{abstract}

Keywords: Electrorheological damper, vibration control, ride comfort, road handling.

\section{ABSTRAK}

Kertas ini membincangkan prestasi sistem ampaian yang melibatkan peredam elektroreologi mod alir dalam mengawal getaran yang tidak diperlukan disebabkan oleh permukaan jalan yang tidak rata. Pertama, model matematik untuk menentukan pemalar redaman daripada peredam dibangunkan berasaskan kepada kelakuan aliran bendalir di dalam sela antara dua elektrod. Untuk menentukan prestasi, sistem tersebut disimulasikan dalam dua jenis ujaan jalan; ujaan tiba-tiba dan ujaan harmonik. Prestasi sistem dicirikan oleh tingkat keselesaan tunggangan dan pengawalan jalan. Keselesaan tunggangan dinilai dengan daya yang dihantarkan daripada jalan kepada penumpang dan oleh pecutan menegak daripada jisim terpegas, manakala pengawalan jalan kenderaan dinilai oleh lonjakan roda dan nisbah penguatan. Hasil yang diperolehi menunjukkan bahawa sistem tersebut dapat mencapai tolak ansur terbaik antara pengawalan jalan dan keselesaan tunggangan melalui pengaturan kekuatan medan elektrik yang diberikan kepada peredam.

Kata kunci: Peredam elektroreologi, kawalan getaran, keselesaan tunggangan, pengawalan jalan. 


\section{INTRODUCTION}

Electrorheological (ER) fluid is a class of dispersion which commonly composed of polarisable solid particles as dispersion phase and non conducting oil as dispersed phase. Upon the imposition of external electric field, the particle will polarised and form a chainlike structure along the directions of the electric field. This structure is responsible for the rheological properties alteration of the ER fluid from a fluid-like state to a solid-like state which exhibits a yield stress. The reversible and dramatic change in the rheological properties of ER fluids coupled with the instant response offers wide potential in industrial application. One of the promised applications is on the vibration control area, especially on semi-active suspension (Petek et al. 1995; Makris et al. 1996; Sassi et al. 2003; Mohamed et al. 2005).

Semi-active suspension system has attracted a great deal of attention since this system combine the best feature of both passive and active control system. This system can achieve the optimum compromise between ride comfort and road handling for several road conditions. To achieve this condition, semi-active system uses a controllable damper, a damper which the damping level can be adjusted. There are two ways to adjust the damping level, whether controlling the fluid properties or modifying the orifice. The latter has a slower response time since it uses electro-mechanical valve mechanism (Suh and Yeo 1999). This method also leads to the inclusion of more moving parts inside of the damper, which could potentially lead to decreased reliability and a shortened lifetime.

The ride comfort and road handling can be evaluated in several ways. Choi and Han (2003) stated that vertical acceleration of the sprung mass and wheel hop are used to evaluate ride comfort and road holding of the vehicle, respectively. Sassi et al. (2003, 2005) used transmissibility and amplification ratio to assessed ride comfort and road handling, respectively. Transmissibility $T r$, defined as the ratio of the transmitted force to the excitation force, and the amplification ratio AR, defined as the ratio of the resulting motion to the excitation motion amplitude. The transmissibility and the amplification ratio can be determined by the following formula (Thomson 1981):

$$
\begin{aligned}
& T r=\frac{\sqrt{1+(2 \zeta r)^{2}}}{\sqrt{\left(1-r^{2}\right)^{2}+(2 \zeta r)^{2}}} \\
& A R=\frac{1}{\sqrt{\left(1-r^{2}\right)^{2}+(2 \zeta r)^{2}}}
\end{aligned}
$$

where $r$ is the ratio between excitation frequency to the natural frequency and $\xi$ is the ratio between actual damping coefficient to the critical damping.

A suspension system of a moving vehicle can encountered two kinds of excitation due to the road surface, which are abrupt or shock excitation and periodic excitation. An abrupt excitation can happen if the vehicle faces a bump or a pothole, while periodic excitation can happen if the vehicle faces an undulating road. In this paper, the abrupt excitation is represented by an impulse while the periodic excitation is represented by a sine wave.

\section{MATHEMATICAL MODEL}

Basically, the flow mode ER-damper consists of piston rod and piston head in concentric cylinder tubes which also act as electrodes (Figure 1). If a certain level of force is given to the piston rod, there will be a pressure drop between upper section and lower section inside the annular gap and the fluid will move with a certain flux or velocity.

In the case where electrode gap $(D)$ is much less than inner electrode diameter $\left(2 R_{1}\right)$, the solution for the Poiselle flow between concentric cylinder collapses to that flow between parallel plates (Makris et al 1996). For the fluid flow between parallel plates, the force equilibrium is (Hughes 1979):

$$
\frac{d \tau}{d r}=\frac{d P}{d x}
$$

where $\tau$ is shear stress, $P$ is pressure developed via piston head movement, $r$ is the radial coordinate and $x$ is the longitudinal coordinate. With the assumption that $P$ varies linearly along the length of the electrode gap, the above equation turns to:

$$
\frac{d \tau}{d r}=\frac{\Delta P}{L}
$$




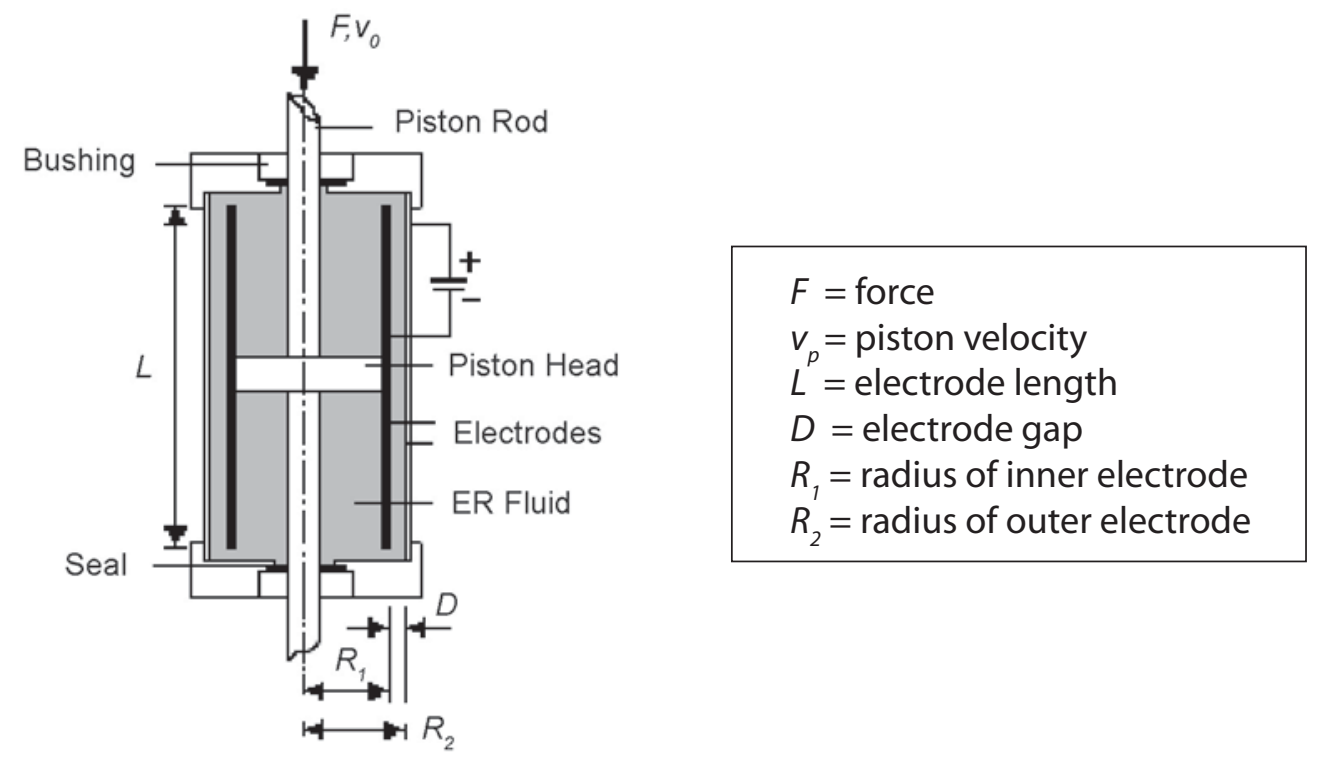

FIGURE 1. Schematic diagram of flow-mode ER damper

Without the application of external electric field, the particle phase of ER fluid is randomly distributed in dispersed phase and act as Newtonian fluid as shown in Figure 2. The shear stress of Newtonian fluid is proportional to the velocity profile gradient through the gap as:

$$
\tau=\mu_{0} \frac{d u}{d r}
$$

$$
\tau(r)=\frac{\Delta P}{2 L}(2 r-D)
$$

The fluid volume flux through the electrodes $\left(Q_{N}\right)$ is obtained via integrating the velocity profile over the annular electrode gap, which is

$$
Q_{N}=\int_{0}^{D} 2 \pi R_{1} u(r) d r=-\frac{\pi R_{1} D^{3} \Delta P}{6 \mu_{0} L}
$$

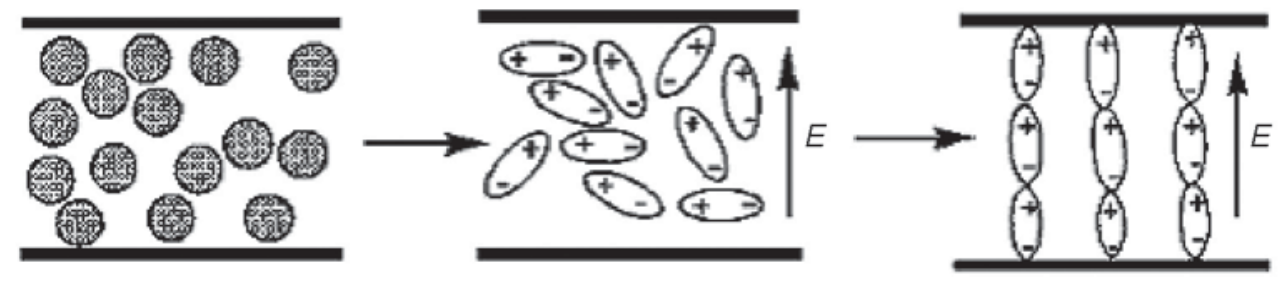

FIGURE 2. Schematic illustrations of the ER particles before and after an electric field is applied. The two parallel dark lines stand for two electrodes while $E$ is electric field (Hao 2002)

where $\mu_{0}$ is viscosity and $u$ is velocity.

By substituting equation (5) to (4) and integrating with respect to $r$, the equation for the Newtonian velocity profile (Figure 3) can be written as:

$$
u(r)=\frac{\Delta P}{2 \mu_{0} L}\left(r^{2}-D r\right)
$$

By inserting the non-slip condition at the boundary such that $u(0)=0$ and $u(D)=0$, yields:
In continuation, the fluid volume flux through annulus $\left(Q_{N}\right)$ is equal to the fluid volume flux displaced by the piston head $\left(Q_{p}\right)$. Since $Q_{P=} A_{p} v_{p}$ and $\Delta P=-F / A_{P^{\prime}}$ yields:

$$
F=\frac{A_{p}^{2} 6 L \mu_{0}}{\pi R_{1} D^{3}} v_{p}
$$

by noting that $F=C_{N} v_{p^{\prime}}$ gives

$$
C_{N}=\frac{A p^{2} 6 L \mu_{0}}{\pi R_{1} D^{3}}
$$




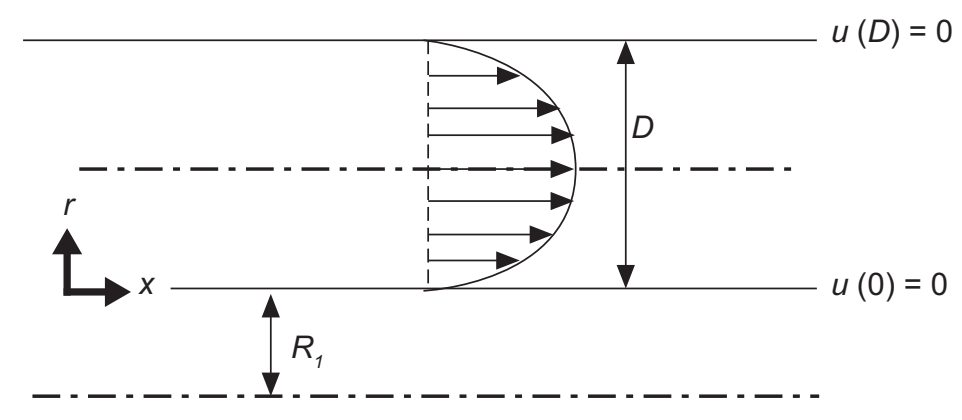

FIGURE 3. Newtonian fluid velocity profile

in the above equations, $A_{p} C_{N}$ and $v_{p}$ are area of piston head minus area of rod,zero-field damping constant and piston head velocity respectively.

In condition that a certain amount of electric field strength applied to ER fluid, the particle phase of the fluid will polarise and form a chainlike structure between the electrodes. The structure will increase the flow resistance of the fluid and the fluid will only flow if the stress given is greater than a critical point called yield stress, $\tau_{y}$. This condition can be modeled by Bingham plastic behaviour (Lindler and Wereley 1999) as:

$$
\tau=\tau_{y} \operatorname{sgn}\left(\frac{d u}{d r}\right)+\mu_{p} \frac{d u}{d r}
$$

The higher the electric field strength applied (E), the higher $\tau_{y}$ will produced. The relationship between $E$ and $\tau_{y}$ is (Kamath et al 1996):

$$
\tau_{y}(E)=\alpha E^{2}+\beta E+\chi
$$

where $\alpha, \beta$ and $\chi$ are the characteristic value for particular ER fluid which obtained via experiment.

The velocity profile of Bingham flow can be divided into three regions. Region 1 and 3 are named as post yield condition while region 2 is named as pre yield condition. In region 1 and 3 , $\tau$ is higher than $\tau_{y}$ so that the material is sheared. On the other hand, $\tau$ in region 2 is lower than $\tau_{y^{\prime}}$ so the material will flow as a plug. For a given force, an increasing in applied electric field will increase the $\tau_{y^{\prime}}$ hence the plug region will get thick.

By substituting equation (11) to (4) and integrating it with respect to $r$, yields general equation for Bingham fluid velocity profile, uB, as:

$$
u_{B}(r)=\frac{\Delta P}{2 \mu_{p} L} r^{2}+c_{1} r+c_{2}
$$

where $c_{1}$ and $c_{2}$ are constant from the integration which values are determined by boundary conditions.

By inserting the boundary condition such as listed in Table 1 into equation (13),yields velocity profile equation for each region as:

$$
\begin{aligned}
& u_{1}(r)=\frac{\Delta P}{2 \mu_{p} L}\left(r^{2}-2 r_{p 1} r\right) \\
& u_{2}(r)=\frac{\Delta P}{2 \mu_{p} L} r_{p 1}^{2} \\
& u_{3}(r)=\frac{\Delta P}{2 \mu_{p} L}\left(r^{2}-2 r_{p 2} r+2 r_{p 2} D-D^{2}\right)
\end{aligned}
$$

By substituting equation (14) and (16) to (11), yields equation for shear stress in region 1 and region 3 as:

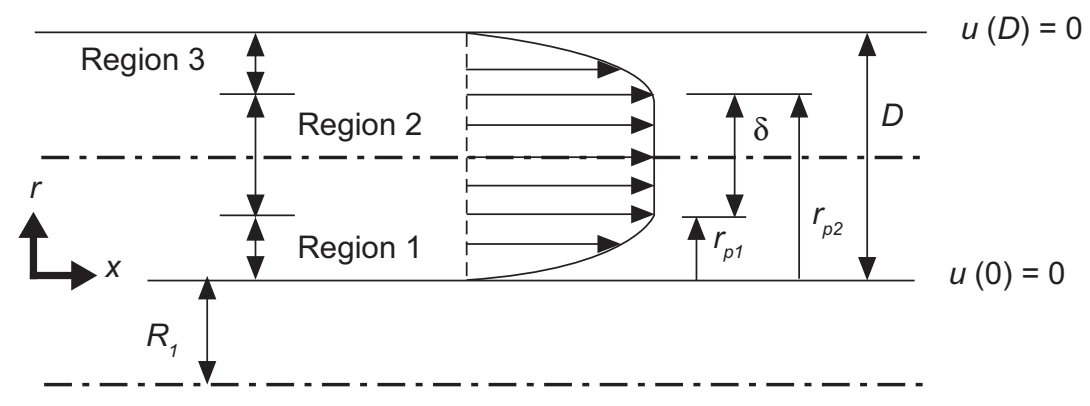

FIGURE 4. Bingham fluid velocity profile 
TABLE 1. Boundary conditions for Bingham fluid flow

\begin{tabular}{|c|c|c|c|c|}
\hline Region & Range & Shear stress & Velocity gradient & Boundary condition \\
\hline 1 & $0<r<r_{p 1}$ & $|\tau|>\left|\tau_{y}\right|$ & $\frac{d u}{d r}>0$ & $u(0)=0 ; \frac{d u}{d r}\left(r_{p 1}\right)=0$ \\
\hline 2 & $r_{p 1}<r<r_{p 2}$ & $|\tau|<\left|\tau_{y}\right|$ & $\frac{d u}{d r}=0$ & $\begin{array}{l}\tau_{2}\left(r_{p 1}\right)=\tau_{y} \\
\tau_{2}\left(r_{p 1}\right)=-\tau_{y}\end{array}$ \\
\hline 3 & $r_{p 2}<r<D$ & $|\tau|>\left|\tau_{y}\right|$ & $\frac{d u}{d r}<0$ & $u(D)=0 ; \frac{d u}{d r}\left(r_{p 2}\right)=0$ \\
\hline
\end{tabular}

$$
\begin{aligned}
& \tau_{1}(r)=\tau_{y}+\frac{\Delta P}{L}\left(r-r_{p 1}\right) \\
& \tau_{3}(r)=-\tau_{y}+\frac{\Delta P}{L}\left(r-r_{p 2}\right)
\end{aligned}
$$

From the integration of equation (4), shear stress in region 2 becomes:

$$
\tau_{2}=\frac{\Delta P}{L} r+c_{3}
$$

The shear stress at the transition zone between plug flow to non-plug flow $\left(r=r_{p 1}\right.$ and $\left(r=r_{p 2}\right)$ is similar to the yield stress of the material or $\tau\left(r_{p 1}\right)=\tau_{y}$ and $\tau\left(r_{p 2}\right)=-\tau_{y}$. By inserting these boundary conditions to equation (19) yields:

$$
\begin{aligned}
& \tau_{y}=\frac{\Delta P}{L} r_{p 1}+c_{3} \\
& -\tau_{y}=\frac{\Delta P}{L} r_{p 2}+c_{3}
\end{aligned}
$$

Subtracting equations (20) to (21) and noting that $\Delta P=-F / A_{p}$ yields equation for plug thickness as:

$$
r_{p 2}-r_{p 1}=\delta=\frac{\tau_{y} A_{p} 2 L}{|F|}
$$

By noting that $r_{p 2}-r_{p 1}=\delta$ and $r_{p 1}+r_{p 2}=D$, (Figure 4) gives equations:

$$
\begin{aligned}
& r_{p 1}=\frac{D-\delta}{2} \\
& r_{p 2}=\frac{D+\delta}{2}
\end{aligned}
$$

Adding equation (14),(15) and (16), integrating it with respect to r over the annular electrode gap and substituting equation (23) and (24) to the result, yields equation for volume flux of Bingham flow as:

$$
Q_{B}=\frac{\pi R_{1} \Delta P D^{3}}{12 \mu_{p} L}\left(1-\frac{\delta}{D}\right)^{2}\left(2+\frac{\delta}{D}\right)
$$

since $\Delta P=-F / A_{p^{\prime}}$ gives:

$$
F_{B}=\frac{12 \mu_{p} L A_{p}^{2}}{\pi R_{1} D^{3}}\left(\left(1-\frac{\delta}{D}\right)^{2}\left(2+\frac{\delta}{D}\right)\right)^{-1} v_{p}
$$

so that the damping constant for Bingham condition, $C_{B^{\prime}}$ is:

$$
C_{B}=\frac{12 \mu_{p} L A_{p}^{2}}{\pi R_{1} D^{3}}\left(\left(1-\frac{\delta}{D}\right)^{2}\left(2+\frac{\delta}{D}\right)\right)^{-1}
$$

For Newtonian condition ( $E=0$ and $\bar{\delta}=0$ ), equation (27) is similar to equation (10).

All of the preceding equation prevail in the assumption that the fluid is incompressible and in fully developed condition and the flow is steady and laminar.

\section{MATERIALS AND METHOD}

To asses the performance of the suspension system that implements the flow-mode ERdamper, some simulations using SIMULINK toolbox in MATLAB were developed. The nominal damper design for the simulation is: $L$ is $200 \mathrm{~mm}$, $R_{1}$ is $26 \mathrm{~mm}, R_{2}$ is $28.5 \mathrm{~mm}, d_{r}$ is $10 \mathrm{~mm}, d_{p}$ is $50 \mathrm{~mm}$, and $D$ is $1.5 \mathrm{~mm} . L, R_{1^{\prime}}, R_{2^{\prime}} d_{r^{\prime}} d_{p^{\prime}}$ and $D$ represents the inner electrode length, inner electrode radius, outer electrode radius, diameter of rod, diameter of piston head and the electrode gap, respectively. The electrorheological fluid used for the simulation is LID 3354, which is made by Smart Technology Ltd. Dynamic viscosity of the fluid is $68.2 \mathrm{mPa}$ s and the relation between yield 
stress with electric field strength is $\tau_{y}=0.26 E^{2} \mathrm{kPa}$ (Smarttec 2005).

To simplified the analysis, the vehicle suspension system was considered as a quarter car model with one degree of freedom (Figure 5). This model still retains many of essential characteristic of a more complex system in its response to excitation (Sassi et al 2003).

$$
C_{c}=2 m_{s} \sqrt{k_{s} / m_{s}}
$$

The vehicle was assumed moving with a constant velocity, $30 \mathrm{~km} / \mathrm{h}$. The height and the wide of the bump for the abrupt excitation simulation is $0.05 \mathrm{~m}$ dan $0.5 \mathrm{~m}$, respectively. The amplitude and the wavelength of the sine wave for the periodic excitation simulation is $0.05 \mathrm{~m}$

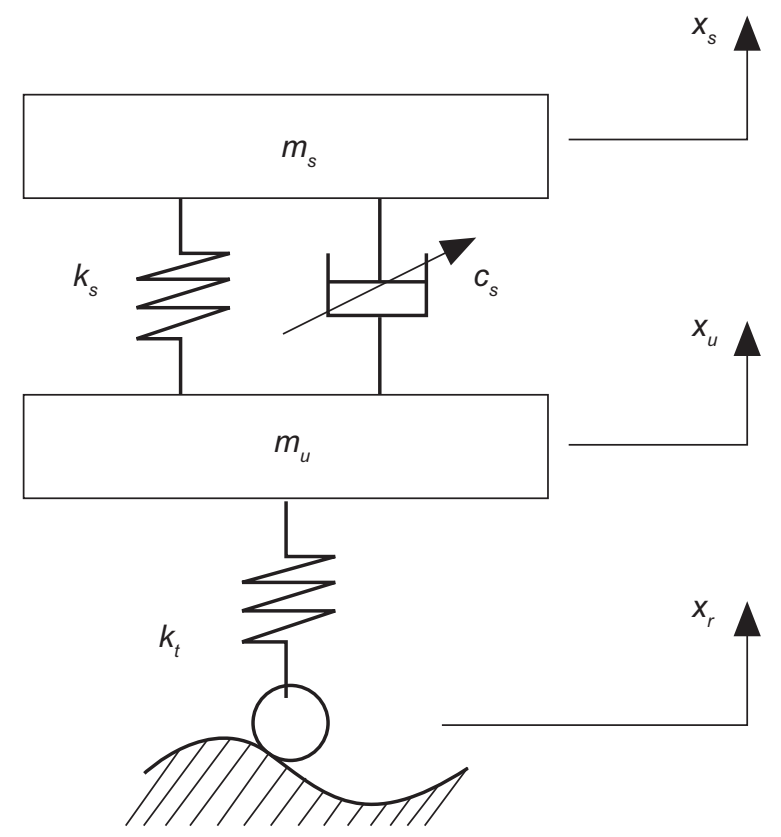

FIGURE 5. Quarter car model

The movement equation of the system above is written in the following form:

$$
\begin{aligned}
& m_{s} \ddot{x}_{s}=k_{s}\left(x_{u}-x_{s}\right)+C\left(\dot{x}_{u}-\dot{x}_{s}\right) \\
& m_{u} \ddot{x}_{u}=k_{t}\left(x_{r}-x_{u}\right)-k_{s}\left(x_{u}-x_{s}\right)+C\left(\dot{x}_{u}-\dot{x}_{s}\right)
\end{aligned}
$$

where $m_{u}$ is the unsprung mass, $m_{s}$ is the sprung mass, $k_{t}$ is the stiffness coefficient of the tire, $k_{s}$ is the stiffness coefficient of the spring and $C_{s}$ is the damping constant, which is influenced by the applied electric field strength. $x_{s^{\prime}} x_{u}$ and $x_{r}$ represents vertical displacement of sprung mass, vertical displacement of unsprung mass and road excitation, respectively. The value for $m_{u^{\prime}} m_{s^{\prime}} k_{t}$ and $k_{s}$ is $37 \mathrm{~kg}, 260 \mathrm{~kg}, 130000 \mathrm{Ns} / \mathrm{m}$ and 13000 $\mathrm{Ns} / \mathrm{m}$, respectively (Mohd Jailani 1983). For these values, the natural frequency of the system is 7.07 $\mathrm{rad} / \mathrm{sec}$ and the critical damping is $3676.96 \mathrm{Ns} / \mathrm{m}$. Mathematical equations that used to obtain the natural frequency $\left(\omega_{n}\right)$ and the critical damping $\left(C_{C}\right)$ are:

$$
\omega_{n}=\sqrt{k_{s} / m_{s}}
$$

and $4.167 \mathrm{~m}$, respectively. Since the excitation frequency is $2 \pi$ times vehicle velocity divided by wavelength, the excitation frequency for this condition is $2 \mathrm{~Hz}$.

For periodic excitation, the passenger ride comfort was evaluated by transmissibility, while the vehicle road handling was evaluated by amplification ratio. For abrupt excitation, the passanger ride comfort was evaluated by vertical acceleration of sprung mass, while the vehicle road handling was evaluated by wheel hop.

\section{RESULT AND DISCUSSION}

By inserting nominal damping design and the properties of the electrorheological fluid to the equation (9) and (26), the relation between force versus velocity can be obtained and the result is plotted in Figure 5.

Using this plot, the damping coefficient (C) for each electric field strength can be obtained from the slope of the best linear curve fitting. The resultant damping coefficient then compared 


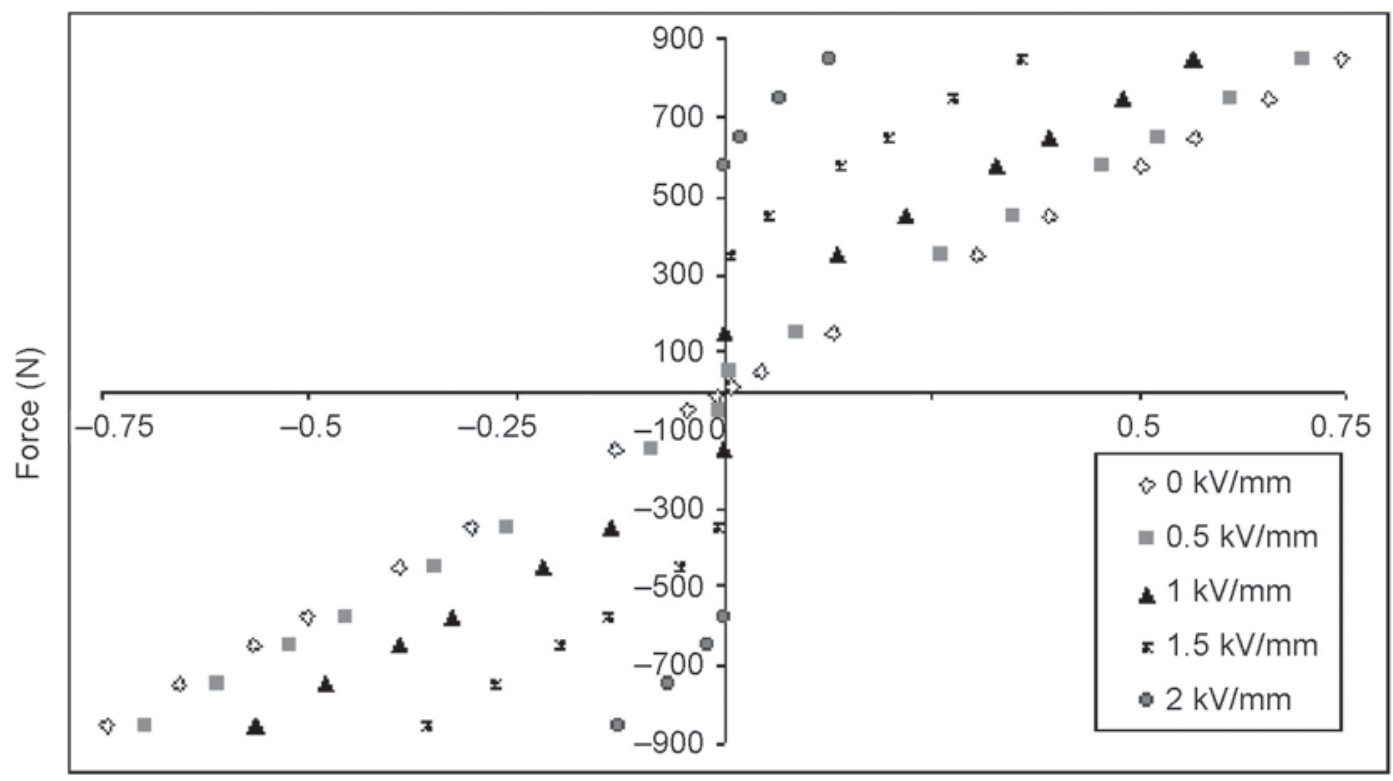

Piston Velocity $(\mathrm{m} / \mathrm{s})$

FIGURE 5. Force versus velocity diagram

with the damping coefficient determined by a mathematical model proposed by Choi et al. (2000) to validate the mathematical model in this paper. From Figure 6, it is clearly seen that both models have a good correlation.

Figure 8 shows the transmissibility and the amplification ratio of the system when itencounters harmonic excitation with the frequency as high as $2 \mathrm{~Hz}$. It is clearly observed from the figure that the increasing of damping level will increase the transmissibility and decrease the amplification ratio. It means that the suspension with high damping level will provide good vehicle stability but gives low comfort. On the other hand, the soft damping level will reduce the transmitted force to the passenger but also reduce the wheel contact to the road surface. The best trade off between comfort and stability is obtained

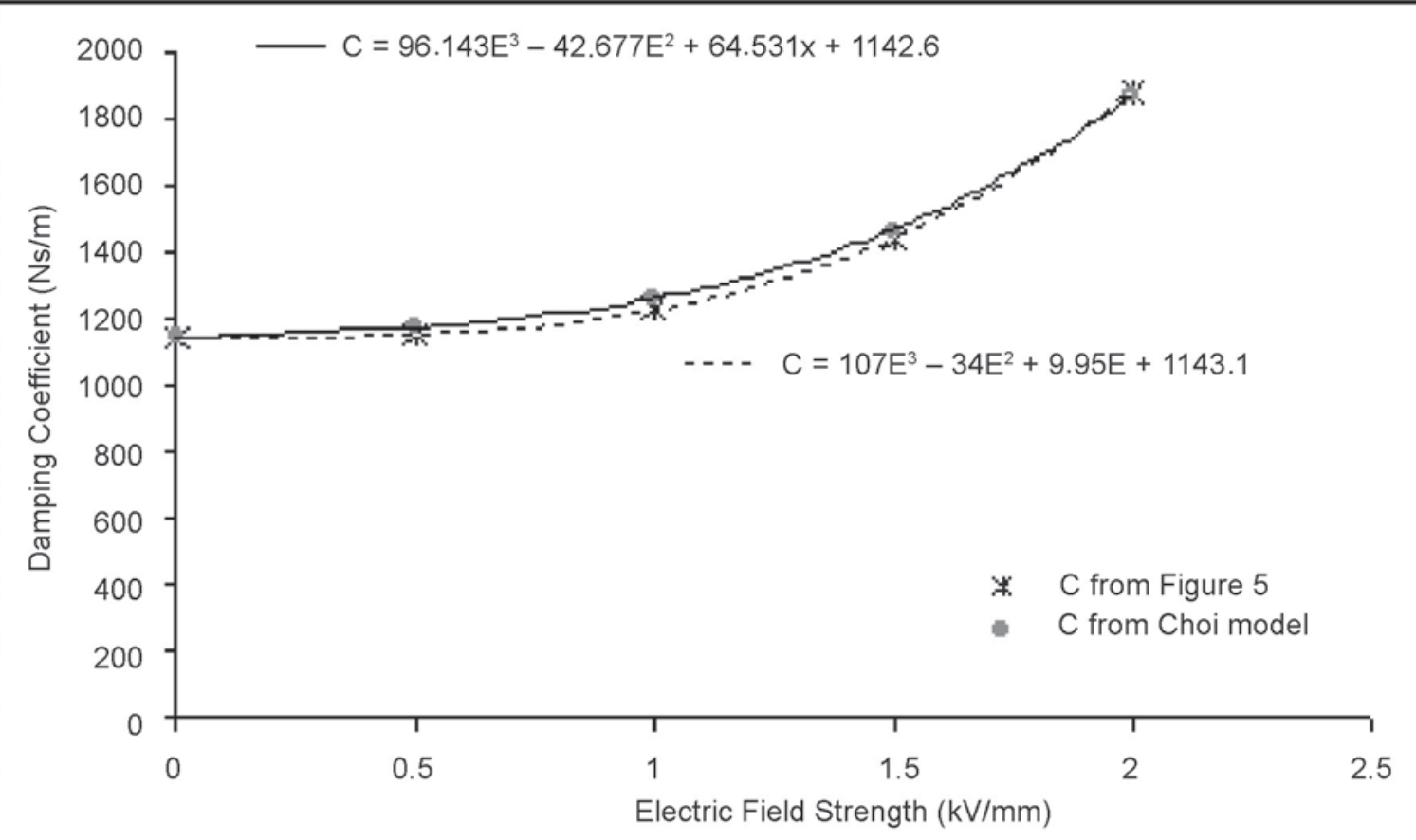

FIGURE 6. Damping coefficient (C) versus applied electric field (E) determined from the slope from Figure 5 and from Choi model 

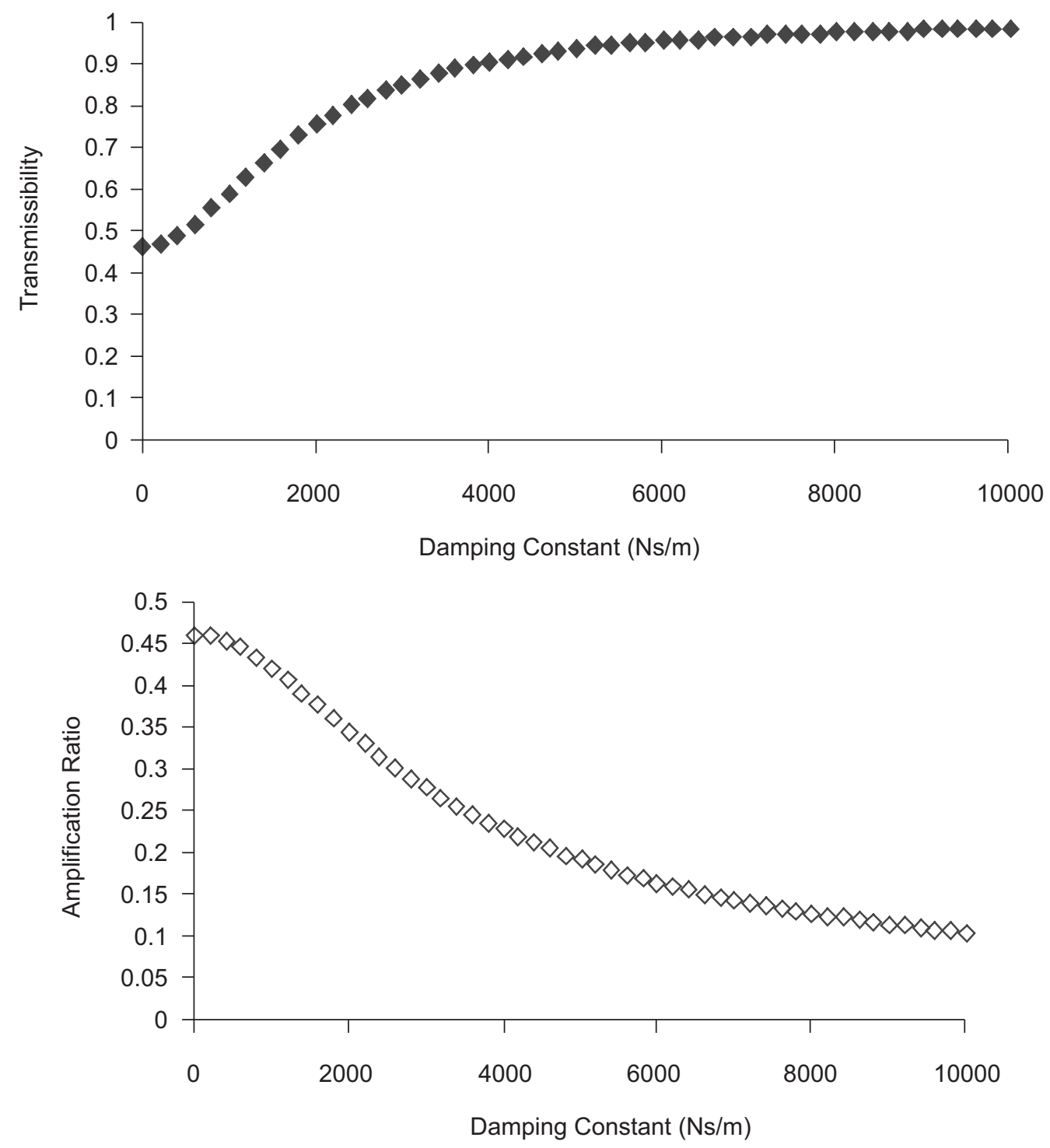

FIGURE 8. Transmissibility and amplification ratio versus damping constant for an excitation frequency of $2 \mathrm{~Hz}$

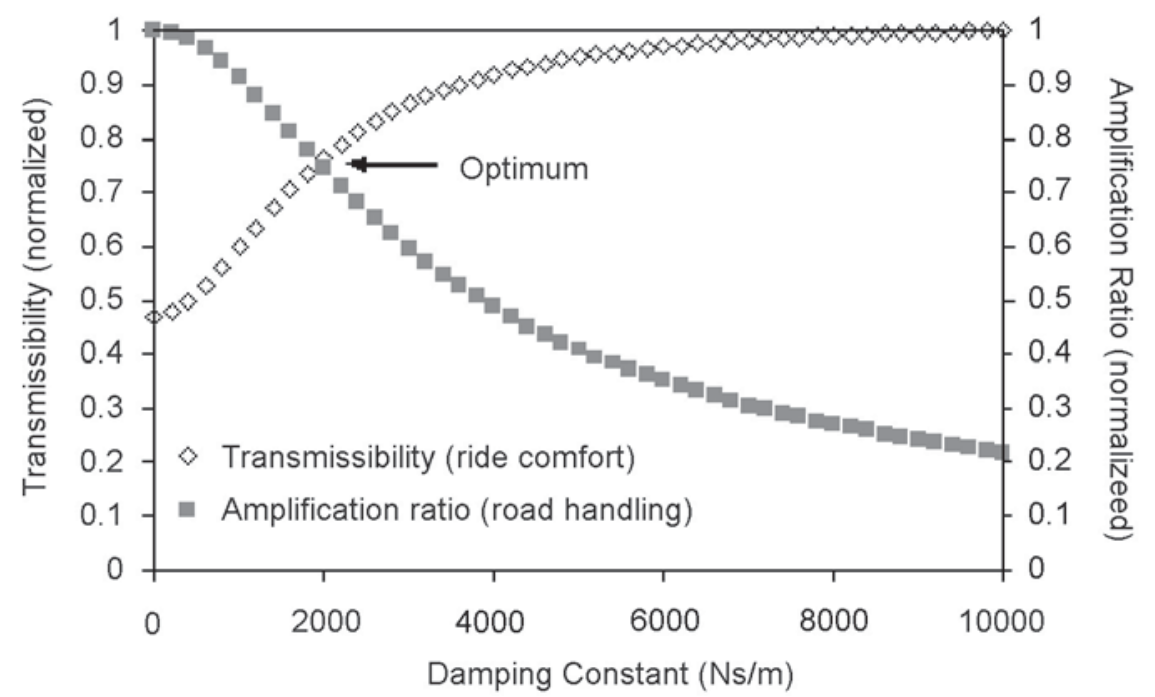

FIGURE 9. Normalised transmissibility and amplification ratio versus damping coefficient for $2 \mathrm{~Hz}$ excitation frequencies 
with the damping value at the intersection between normalised amplification ratio curve and the normalised transmissibility curve (Figure 9). Recalling the relationship between applied electric field strength to the damping coefficient, the strength of the applied electric field that required to achieve the optimum damping level is about $1.89 \mathrm{kV} / \mathrm{mm}$.

Figure 10 and Figure 11 shows the effect of the applied electric field strength to the performance of the suspension system when it encounters an abrupt excitation (bump).

As depicted by Figure 10, it can be observed that vertical acceleration of the sprung mass in off-field condition has a lower amplitude compared to the on-field condition. The low amplitude corresponden to the low force that is transmited to the passenger, which means good ride comfort. The damping constant of the damper in off-field condition is 1142.6 $\mathrm{N} / \mathrm{ms}$ while in the application of $2.5 \mathrm{kV} / \mathrm{mm}$ electric field, the damping constant increase to $2539.43 \mathrm{~N} / \mathrm{ms}$. A soft damper (a damper with a low damping constant) will allow the spring to oscilate more freely. The more the oscilation, the greater vibration force that is absorp by the spring, which in turns, the lower the force that is transmitted to the passenger.

However, as depicted by Figure 11, the wheel hop in off-field condition has a higher positive amplitud and a higher number of oscilation compared to the on-field condition. The high number of oscilation and a high positive amplitude represent the tendency of the wheel to loose contact with the road surface, which can reduce the stability of the vehicle. Hence, there will be a condition where the level of the ride comfort and the road handling achieve the

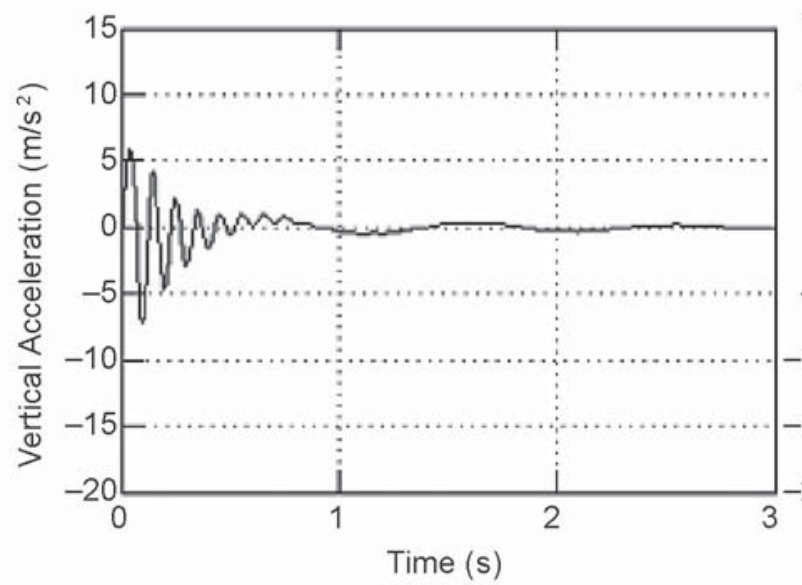

(a)

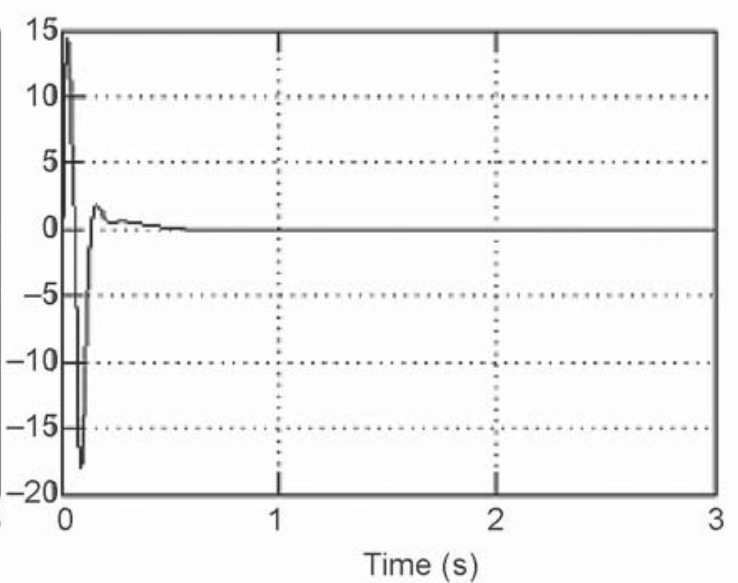

(b)

FIGURE 10. Sprung mass vertical acceleration versus time for bump excitation (a) 0kV/mm, (b) $2.4 \mathrm{kV} / \mathrm{mm}$

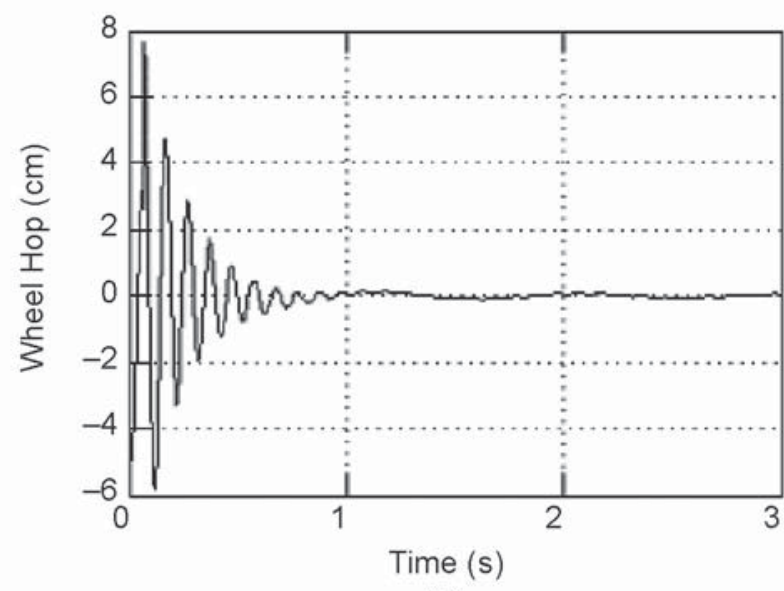

(a)

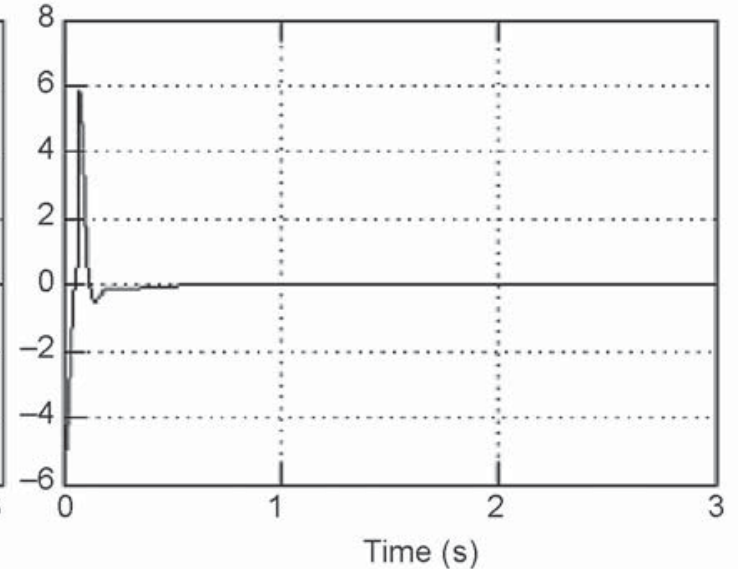

(b)

FIGURE 11. Wheel hop versus time for bump excitation (a) $0 \mathrm{kV} / \mathrm{mm}$, (b) $2.4 \mathrm{kV} / \mathrm{mm}$ 
optimum point. This condition can be achieved by adjusting the strength of the applied electric field.

\section{CONCLUSION}

The mathematical equation that relates the electric field strength to the damping constant of the damper has discussed in detail in this paper. As depicted by the equation, the damping level of the flow mode ER-damper was determined by the viscosity of the fluid, the area of the piston, the electrode length, the electrode gap and the applied electric field strength. The result

\section{REFERENCES}

Choi, S.B., Choi, Y.T. \& Park, D.W. 2000. A Sliding mode control of a full car electrorheological suspension system via hardware-in-the-loop simulation. ASME Journal of Dynamic Systems, Measurements and Control. 122: 114-121.

Hao,T.2002.Electrorheological Suspensions.Advances in Colloid and Interface Science 97: 1-35.

Hughes, W.F. 1979. An introduction to viscous flow. Washington: Hemisphere Publishing Corporation.

Kamath, G.M.,Hurt, M.K.\& Wereley, N.M. 1996. Analysis and testing of Bingham plastic behavior in semiactive electrorheological fluid dampers. Smart Materials and Structures 5:576-590.

Lindler, J. and Wereley, N.M. 1999. Analysis and testing of Electrorheological Bypass Damper. Journal of Intelligent Material System and Structures 10 (5):351-429.

Makris, N., Burton, S.A. \& Taylor, D.P. 1996. Electrorheological damper with annular ducts for seismic protection applications. Smart Materials and Structures 5:551-564.

Mohd Jailani, M.N. 1983. The study of semi-active automobile suspension. Master of Science Thesis. Oklahoma State University. Oklahoma. obtained from the simulation clearly shows that the suspension system that implements the flow-mode ER-damper can achieve the best compromise between the ride comfort and road handling by adjusting the applied electric field strength.

\section{ACKNOWLEDGMENT}

The authors would like to thank to the Malaysian Ministry of Science, Technology and Environment for sponsoring this research under IRPA 03-02-020016 SR0003/07-02 research grant.

Mohamed N.A.N., Nor M.J.M., \& Mukhlis R. Z. 2005. Compromising Vehicle Handling and Passenger Ride Comfort Using ER Damper. Mechanika 4(54):50-54.

Petek, N.K., Romstad, D.L., Lizell, M.B.\& Weyenberg, T.R. 1995. Demonstration of an automotive semiactive suspension using electrorheological fluid. SAE Technical Paper Series 9505861995.

Sassi, S., Cherif, K. \& Thomas, M. 2003. On the design and testing of a smart car damper based on electro-rheological technology.Smart Materials and Structures 12:873-880.

Sassi, S., Cherif, K., Mezghani, L., Thomas, M. \& Kotrane, A. 2005. An innovative magnetorheological damper for automotive suspension: from design to experimental characterization. Smart Materials and Structures 14:811-822.

Smarttec Ltd. 2005. ER-Fluid properties. http://www. smarttec.co.uk/erf.html. (12 September 2005).

Suh, M.S. \& Yeo, M.S. 1999. Development of semiactive suspension system using ER fluids for the wheeled vehicle. Journal of Intelligent Material Systems and Structures 10(9): 743-747.

Thomson, W.T., 1981. Theory of Vibration with Applications. $2^{\text {nd }}$ Edition. New Jersey: PrenticeHall Inc. 